\title{
Pengaruh Fundamental Ekonomi Daerah dalam Pembangunan Ekonomi di Kota Sungai Penuh Tahun 2010-2015
}

\author{
Silvia Rahayu \\ Sekolah Tinggi Ilmu Ekonomi (STIE) Sakti Alam Kerinci \\ Email : silviarhy1038@ gmail.com
}

\begin{abstract}
This research has a purpose to know to know the influence of economic growth, income per capita and HDI to economic development in Sungai Penuh City either simultaneously or partially and to know how relation of bamboo handicraft production development seen from aspect of labor, raw material and capital to effort of poverty Poverty in Siulak Subdistrict Based on the results of analysis using multiple linear regression analysis obtained results: 1. Regional economic fundamentals consisting of economic growth, income per capita and HDI have a significant influence on economic development either simultaneously or partially. The amount of influence of regional economic fundamentals on economic development is as follows: a. Simultaneously, $F$ value counted 529,104 while F table $(\alpha=0.05 ;$ db regression $=4: d b$ residual $=2)$ was 19.25. Because $F$ arithmetic $>F$ table is 529,104>19,25 then regression analysis is significant. This means that $\mathrm{HO}$ is rejected and $\mathrm{H1}$ accepted so it can be concluded that economic development in Kota Sungai Penuh 2010-2015 can be significantly influenced by free variable of regional economic fundamentals that is economic growth variable, income per capita and HDI. B. Partially, $t$ arithmetic XI (economic growth) $=4.836$ and $t$ table of 2.920. Because $t$ arithmetic $>t$ table is 4.836> 2.920 and from the table obtained a significance value of 0.008 , then the influence of XI (economic growth) is significant. This means that HO is rejected and $\mathrm{HI}$ accepted, so it can be concluded that economic development in Kota Sungai Penuh can be significantly influenced by real economic growth variable. From the coefficient value is known that economic growth has an effect of $0.139 \%$ on economic development. $T$ arithmetic X2 (income per capita) $=6,813$ and t table is equal to 2,920. Because t arithmetic>t table is 6.813>2.920 and from the table obtained value of significance 0.019, then the influence of X2 (income per capita) is significant. This means that $\mathrm{HO}$ is rejected and $\mathrm{HI}$ is accepted, so it can be concluded that economic development in Kota Sungai Penuh can be significantly influenced by per capita income variable significantly. From the coefficient value is known that income per capita have influence equal to 0,886\% to economic development. $T$ arithmetic X3 $(I P M)=6.602$ and t table of 2.920. Because $t$ arithmetic> $t$ table is 6.602> 2.920 and from the table obtained value of significance 0.027, then the influence of X3 (HDI) is significant. This means that $\mathrm{HO}$ is rejected and $\mathrm{HI}$ accepted, so it can be concluded that economic development in Kota Sungai Penuh can be significantly influenced by real HDI variable. From the coefficient value is known that the HDI has an effect of $2.366 \%$ of economic development.
\end{abstract}

Keywords : Economic Growth, Per Capita Income, HDI

\section{PENDAHULUAN}

Pembangunan

multidimensional suatu daerah haruslah mencakup tiga inti nilai pertama, ketahanan (sustenance) yaitu kemampuan untuk memenuhi kebutuhan pokok (sandang, pangan, papan, kesehatan dan proteksi) untuk mempertahankan hidup. Kedua, harga diri (self esteem) yaitu pembangunan haruslah memanusiakan orang (Todaro, 2006:42). Pembangunan suatu daerah dalam arti luas haruslah meningkatkan kebanggaan sebagai manusia yang berada di daerah itu. Ketiga, kebebasan (freedom from servitude) yaitu kebebasan bagi setiap individu suatu negara untuk berpikir, berkembang, berperilaku dan berusaha 
untuk berpartisipasi dalam pembangunan.

Human Development Index
(HDI) mengukur capaian pembangunan manusia berdasarkan sejumlah komponen dasar kualitas hidup yaitu capaian umur panjang dan sehat (angka harapan hidup), angka melek huruf dan rata-rata lama sekolah serta kemampuan daya beli terhadap kebutuhan pokok yang dilihat dari rata-rata besarnya pengeluaran per kapita sebagai pendapatan. Konsekuensi dari kualitas proses pembangunan adalah peningkatan kualitas sumber daya manusia. Penempatan manusia sebagai subyek pembangunan menekankan pada pentingnya pemberdayaan (empowerment) manusia, yaitu kemampuan untuk mengaktualisasikan segala potensi yang dimiliki masingmasing individu. Keterkaitan sasaran fundamental ekonomi daerah antara pembangunan manusia dan pertumbuhan ekonomi dapat dilihat dari hasil penelitian Bank Pembangunan Asia (2007:132), yang menemukan bahwa pembangunan manusia berpengaruh positif terhadap pertumbuhan ekonomi baik secara langsung maupun tidak langsung. Pengaruh langsung pembangunan manusia terhadap pertumbuhan ditemukan bahwa tingkat melek huruf yang tinggi, tingkat kematian bayi yang rendah dan tingkat kesenjangan serta kemiskinan yang rendah, memberikan kontribusi positif terhadap pertumbuhan ekonomi yang sangat cepat di Asia Timur dan Tenggara. Pengaruh tidak langsung pembangunan manusia terhadap pertumbuhan ekonomi ditemukan melalui konsolidasi demokrasi. Tingkat melek huruf yang tinggi, kesehatan yang baik dan kesamaan kesempatan memungkinkan partisipasi masyarakat dalam proses politik dan membantu membangun konsensus atas tujuan pembangunan.

Secara makro, struktur fundamental dan kinerja perekonomian suatu daerah dapat dilihat dari kinerja dan nilai tambah sektor ekonomi yang menjadi leading sektor pada daerah tersebut. Untuk perekonomian daerah, secara makro ekonomi dapat dilihat dari sektor andalan yang telah menjadi leading sector perekonomian selama ini. Berdasarkan kinerja tersebut, masalah dan kebijakan pembangunan terutama mengenai PDRB, distribusi, nilai tambah, analisis dampak output, pendapatan perkapita, penyerapan tenaga kerja, serta keterkaitan antar sektor dari variabel sosial-ekonomi dan lingkungan yang berkelanjutan dapat dikaji. Selanjutnya, berdasarkan kinerja tersebut, dapat direkomendasikan untuk formulasi kebijakan guna mengatasi permasalahan kemiskinan, pengangguran dan peningkatan pertumbuhan ekonomi daerah yang bersangkutan. Masalah kemiskinan, pengangguran dan pemerataan distribusi pendapatan merupakan masalah pokok yang teramat penting bagi pembangunan ekonomi Indonesia. Sejak tiga dasa warsa yang lalu, berbagai analisis ekonomi telah dilakukan untuk mengamati apakah sebuah kebijakan ekonomi dapat mengurangi kemiskinan dan membuat distribusi pendapatan semakin merata di suatu negara.

Tujuan utama kebijakan setiap daerah yang sedang membangun diarahkan untuk mencapai kesejahteraan masyarakat. Masalah pokok yang dihadapi daerah yang sedang membangun adalah kesejangan antarsektor, antardaerah, antargolongan, ketimpangan distribusi pendapatan serta masalah kemiskinan dan pengangguran. Semua masalah tersebut saling terkait dan sulit untuk dipecahkan secara terpisah. Dalam perekonomian Indonesia, pemerintah merupakan pengambil keputusan utama kebijakan. Tujuannya untuk menghilangkan berbagai masalah pokok di atas agar setiap anggota masyarakat dapat menikmati hasil pembangunan secara merata dan adil.

Kemampuan ekonomi daerah dalam kaitannya dengan daya saing daerah adalah bahwa kapasitas ekonomi daerah harus memiliki daya tarik (attractiveness) bagi pelaku ekonomi yang telah berada dan akan masuk ke suatu daerah untuk menciptakan multiflier effect bagi 
peningkatan daya saing daerah. Namun pertumbuhan ekonomi yang tinggi tidak serta merta membawa tingkat kesejahteran masyarakat menjadi lebih sejahtera, tetapi pertumbuhan tersebut hanya dinikmati oleh sekelompok kecil masyarakat, sedangkan masyarakat lain tidak menikmati.

Kota Sungai penuh merupakan salah satu daerah pemekaran dari Kabupaten Kerinci yang dibentuk melalui Undang-Undang Nomor 25 Tahun 2008 tentang Pembentukan
Kota Sungai Penuh di Provinsi Jambi. Perkembangan perekonomian Kota Sungai Penuh yang diikuti dengan pertambahan jumlah penduduk akan berdampak pada pertumbuhan ekonomi. Tingkat kesejahteraan suatu daerah salah satunya dapat tercermin dari besarnya pertumbuhan ekonomi , pendapatan perkapita, indeks pembangunan mansuian (IPM) dan lain-lain. Berikut ini adalah tabel pertumbuhan ekonomi, pendapatan perkapita dan IPM di Kota Sungai Penuh tahun 2010-2015.

Tabel 1

Pertumbuhan Ekonomi, Pendapatan Perkapita ADHK dan IPM di Kota Sungai Penuh Tahun 2010-2015

\begin{tabular}{cccc}
\hline Tahun & $\begin{array}{c}\text { Pertumbuhan } \\
\text { Ekonomi (\%) }\end{array}$ & $\begin{array}{c}\text { Pendapatan Perkapita } \\
\text { ADHK (Rp) }\end{array}$ & $\begin{array}{c}\text { Indeks Pembangunan } \\
\text { Manusia (IPM) }\end{array}$ \\
\hline 2010 & 5,83 & $1.845 .135,16$ & 69,91 \\
2011 & 6,86 & $3.284 .474,28$ & 70,55 \\
2012 & 7,09 & $3.479 .908,06$ & 71,23 \\
2013 & 8,45 & $3.072 .954,22$ & 72,09 \\
2014 & 7,54 & $3.413 .215,18$ & 72,48 \\
2015 & 7,06 & $3.625 .060,51$ & 73,03 \\
\hline
\end{tabular}

Sumber : Badan Pusat Statistik Kota Sungai, 2015

Tabel 1 diatas terlihat bahwa pertumbuhan ekonomi di Kota Sungai Penuh selalu mengalami peningkatan setiap tahun, hanya pada tahun 2014 mengalami penurunan dari $8,45 \%$ tahun 2013 menjadi 7,54\%. Sedangkan pendapatan per kapita mengalami peningkatan setiap tahun dari $\mathrm{Rp}$. 1.845.135,16 tahun 2010 menjadi Rp. 3.625.060,51 sampai tahun 2015. Indeks pembangunan manusia selalu mengalami peningkatan yang menempatkan Kota Sungai Penuh sebagai peringkat kedua setelah Kota Jambi dan selalu mengalami peningkatan setiap tahun dari 69,91 tahun 2010 menjadi 73,03 tahun 2015.

\section{METODE}

Dalam penelitian ini menempuh metoda penelitian berupa studi kepustakaan (library research) yakni dengan cara pengambilan data yang dilakukan dengan membaca buku-buku, literatur-literatur serta tulisan ilmiah yang berkaitan dengan masalah yang dibahas. Pengambilan data dilakukan pada Badan Pusat Statistik (BPS) Kota Sungai Penuh dan Badan Perencanaan Pembangunan Daerah (Bappeda) Kota Sungai Penuh dan sumber data lainnya.

\section{HASIL}

Pengujian $F$ simultan atau pengujian model digunakan untuk mengetahui apakah hasil dari analisis regresi secara simultan signifikan atau tidak, dengan kata lain model yang diduga tepat/sesuai atau tidak. Jika hasilnya signifikan, maka H0 ditolak dan H1 diterima. Sedangkan jika hasilnya tidak signifikan, maka $\mathrm{HO}$ diterima dan $\mathrm{H} 1$ ditolak. Hal ini dapat juga dikatakan sebagai berikut : H0 ditolak jika $\mathrm{F}$ hitung $>\mathrm{F}$ tabel $\mathrm{H} 0$ diterima jika $\mathrm{F}$ hitung $<\mathrm{F}$ tabel dengan menggunakan tingkat signifikansi $(\alpha=$ 0,05). Adapun hasil dari pengujian secara simultan dapat dilihat pada Tabel 2 berikut. 
Tabel 2

Uji F/Serempak

\begin{tabular}{|l|l|r|r|r|r|c|}
\hline \multicolumn{7}{|c|}{ ANOVA $^{\mathbf{a}}$} \\
\hline Model & Sum of Squares & df & Mean Square & F & Sig. \\
\hline \multirow{3}{*}{1} & Regression &, 018 & 4 &, 009 & 529,104 &, $004^{\mathrm{b}}$ \\
\cline { 2 - 7 } & Residual &, 000 & 2 &, 000 & & \\
\cline { 2 - 7 } & Total &, 018 & 6 & & & \\
\hline \multicolumn{7}{|l|}{ a. Dependent Variable: pdrb_Y } \\
\hline
\end{tabular}

Sumber : Data diolah

Tabel 2 menjelaskan bahwa nilai $\mathrm{F}$ hitung sebesar 529,104. Sedangkan F tabel $(\alpha=0.05 ; \mathrm{db}$ regresi $=4: \mathrm{db}$ residual $=2$ ) adalah sebesar 19,25. Karena F hitung > F tabel yaitu 529,104>19,25 maka analisis regresi adalah signifikan. Hal ini berarti $\mathrm{H} 0$ ditolak dan $\mathrm{H} 1$ diterima sehingga dapat disimpulkan bahwa pembangunan ekonomi di Kota Sungai Penuh tahun 2010-2015 dapat dipengaruhi secara signifikan oleh variabel bebas fundamental ekonomi daerah yaitu variabel pertumbuhan ekonomi, pendapatan perkapita dan IPM.

Uji t Parsial Digunakan untuk menunjukkan apakah masing masing variabel independen berpengaruh terhadap variabel dependen.
Ho $=0$ : diduga tidak terdapat pengaruh yang signifikan antara variabel indenpenden terhadap variabel dependen.

Ho $\neq 0$ : diduga terdapat pengaruh yang signifikan antara variabel indenpenden terhadap variabel dependen.

Dapat juga dikatakan jika $\mathrm{t}$ hitung $>\mathrm{t}$ tabel atau -t hitung $<-\mathrm{t}$ tabel maka hasilnya signifikan dan berarti $\mathrm{H} 0$ ditolak dan H1 diterima. Sedangkan jika $t$ hitung $<\mathrm{t}$ tabel atau t hitung $>-t$ tabel maka hasilnya tidak signifikan dan berarti H0 diterima dan H1 dengan menggunakan tingkat signifikansi $(\alpha=0,05)$. Nilai t test disajikan dalam Tabel 3. berikut.

Tabel 3

Uji t /Parsial

Coefficients $^{\mathrm{a}}$

\begin{tabular}{|c|c|c|c|c|c|c|}
\hline \multicolumn{2}{|c|}{ Model } & \multicolumn{2}{|c|}{ Unstandardized Coefficients } & \multirow{2}{*}{$\begin{array}{l}\text { Standardized } \\
\text { Coefficients } \\
\text { Beta }\end{array}$} & \multirow[t]{2}{*}{$\mathrm{t}$} & \multirow[t]{2}{*}{ Sig. } \\
\hline & & B & Std. Error & & & \\
\hline \multirow[t]{4}{*}{1} & (Constant) & 1,416 & ,006 & & 184 & 004 \\
\hline & $\begin{array}{l}\text { pertumbuhanekonomi_ } \\
\text { x1 }\end{array}$ & 139 & ,077 & , 130 & 4,836 & ,008 \\
\hline & $\begin{array}{l}\text { pendapatanperkapita_x } \\
2\end{array}$ & 886 & 146 & 826 & 6,813 & ,019 \\
\hline & ipm_x3 & 2,366 & 122 & ,389 & 6,602 & ,027 \\
\hline
\end{tabular}

Sumber : Data diolah

Tabel 3 menjelaskan bahwa nilai $\mathrm{t}$ test antara $\mathrm{X} 1$ (pertumbuhan ekonomi), X2 (pendapatan perkapita) dan X3 (IPM) dengan Y (PDRB ADHB) menunjukkan yang diperoleh hasil sebagai berikut :

1. $\mathrm{t}$ hitung $\mathrm{X} 1$ (pertumbuhan ekonomi $=4,836$ dan $\mathrm{t}$ tabel $(\alpha=$ $0.05 ; \mathrm{db}$ residual $=2$ ) adalah sebesar 2,920. Karena t hitung $>\mathrm{t}$ tabel yaitu 4,836 > 2,920 serta dari tabel diperoleh nilai signifikansi 0,008 , sedangkan dalam pengujian menggunakan alpha sebesar 0,05 hal ini berarti nilai signifikansi $0,008<0,05$ maka pengaruh X1 (pertumbuhan ekonomi) adalah signifikan. Hal ini berarti $\mathrm{H} 0$ 
ditolak dan H1 diterima, sehingga dapat disimpulkan bahwa pembangunan ekonomi di Kota Sungai Penuh dapat dipengaruhi secara signifikan oleh variabel pertumbuhan ekonomi atau dengan kata lain bahwa pertumbuhan ekonomi merupakan faktor yang dapat meningkatkan pembangunan ekonomi di Kota Sungai Penuh secara nyata.

2. $\mathrm{t}$ hitung $\mathrm{X} 2$ (pendapatan perkapita $)=6,813$ dan $\mathrm{t}$ tabel $(\alpha=$ $0.05 ; \mathrm{db}$ residual $=2$ ) adalah sebesar 2,920. Karena $t$ hitung $>t$ tabel yaitu 6,813> 2,920 serta dari tabel diperoleh nilai signifikansi 0,019 , sedangkan dalam pengujian menggunakan alpha sebesar 0,05 hal ini berarti nilai signifikansi $0,019<0,05$ maka pengaruh X2 (pendapatan perkapita) adalah signifikan. Hal ini berarti $\mathrm{HO}$ ditolak dan $\mathrm{H} 1$ diterima, sehingga dapat disimpulkan bahwa pembangunan ekonomi di Kota Sungai Penuh dapat dipengaruhi secara signifikan oleh variabel pendapatan perkapita atau dengan kata lain bahwa pendapatan perkapita merupakan faktor yang dapat meningkatkan pembangunan ekonomi di Kota Sungai Penuh secara nyata.

3. $\mathrm{t}$ hitung $\mathrm{X} 3(\mathrm{IPM})=6,602$ dan $\mathrm{t}$ tabel $(\alpha=0.05 ; \mathrm{db}$ residual $=2)$ adalah sebesar 2,920. Karena $t$ hitung > t tabel yaitu 6,602 > 2,920 serta dari tabel diperoleh nilai signifikansi 0,027 , sedangkan dalam pengujian menggunakan alpha sebesar 0,05 hal ini berarti nilai signifikansi $0,027<0,05$ maka pengaruh X3 (IPM) adalah signifikan. Hal ini berarti $\mathrm{H} 0$ ditolak dan $\mathrm{H} 1$ diterima, sehingga dapat disimpulkan bahwa pembangunan ekonomi di Kota Sungai Penuh dapat dipengaruhi secara signifikan oleh variabel IPM atau dengan kata lain bahwa IPM merupakan faktor yang dapat meningkatkan pembangunan ekonomi di Kota Sungai Penuh secara nyata.
Berdasarkan pada Tabel 3 di atas diperoleh persamaan regresi dan besarnya pengaruh nilai variabel $\mathrm{X} 1$, $\mathrm{X} 2, \mathrm{X} 3$ dan Y sebagai berikut :

$\mathrm{Y}=1,416+0,139 \mathrm{X} 1+0,886 \mathrm{X} 2+$ $2,366 \times 3$.

$\mathrm{a}=1,416$ merupakan nilai konstanta, yaitu jika pertumbuhan ekonomi, pendapatan perkapita dan IPM bernilai nol, maka pembangunan ekonomi Kota Sungai Penuh sebesar 0,139\%.

$\beta 1=$ Nilai koefisien regresi pertumbuhan ekonomi sebesar 0,139 , jika pertumbuhan ekonomi meningkat sebesar $1 \%$ (satu persen), maka pembangunan ekonomi Kota Sungai Penuh akan meningkat sebesar $0,139 \%$, dengan asumsi variabel yang lainnya konstan.

$\beta 2=$ Nilai koefisien regresi pendapatan perkapita sebesar 0,886 , jika pendapatan perkapita meningkat sebesar Rp. 1.000.000 (satu juta rupah), maka pembangunan ekonomi Kota Sungai Penuh akan meningkat sebesar $0,886 \%$, dengan asumsi variabel yang lainnya konstan.

$\beta 3=$ Nilai koefisien regresi IPM sebesar 2,366, jika IPM meningkat sebesar 1 (satu), maka pembangunan ekonomi Kota Sungai Penuh akan meningkat sebesar 2,366\%, dengan asumsi variabel yang lainnya konstan.

Berdasarkan interpretasi di atas, dapat diketahui besarnya kontribusi variabel bebas terhadap variabel terikat, antara lain pertumbuhan ekonomi sebesar $0,139 \%$, pendapatan perkapita sebesar $0,886 \%$ dan IPM sebesar $2,366 \%$.

Sehingga dapat disimpulkan bahwa pertumbuhan ekonomi (X1), pendapatan perkapita (X2) dan IPM (X3) berpengaruh positif terhadap pembangunan ekonomi atau apabila pertumbuhan ekonomi (X1), pendapatan perkapita (X2) dan IPM (X3) meningkat, maka akan diikuti peningkatan pembangunan ekonomi.

Analisis Koefisien Determinasi digunakan untuk melihat berapa besar pengaruh variabel $\mathrm{x}$ terhadap variabel y. Dari analisis perhitungan diperoleh nilai $\mathrm{R}^{2}$ (koefisien determinasi) dan koefisien korelasi (R) seperti dalam Tabel 4. berikut. 
Tabel 4.

Koefisien Determinasi

Model Summary ${ }^{\mathrm{b}}$

\begin{tabular}{|c|c|c|c|c|c|}
\hline Model & $\mathrm{R}$ & R Square & $\begin{array}{l}\text { Adjusted R } \\
\text { Square }\end{array}$ & $\begin{array}{l}\text { Std. Error of } \\
\text { the Estimate }\end{array}$ & Durbin-Watson \\
\hline 1 & ,948 & ,955 & ,952 & ,00361 & 2,930 \\
\hline
\end{tabular}

Sumber : Data diolah

Tabel 4 menjelaskan bahwa koefisien determinasi $\mathrm{R}^{2}$ sebesar 0,954 Artinya bahwa $94,8 \%$ variabel pembangunan ekonomi dapat dijelaskan oleh variabel bebasnya, yaitu pertumbuhan ekonomi, pendapatan perkapita dan IPM. Sisanya $5,2 \%$ dipengaruhi oleh variabel lain diluar penelitian ini. Selain koefisien determinasi, juga didapat koefisien korelasi yang menunjukkan besarnya hubungan antara variabel bebas yaitu pembangunan ekonomi dengan variabel pertumbuhan ekonomi, pendapatan perkapita dan IPM, nilai $\mathrm{R}$ (koefisien korelasi) sebesar 0,948 nilai korelasi ini menunjukkan bahwa hubungan antara variabel pertumbuhan ekonomi, pendapatan perkapita dan IPM dengan variabel pembangunan ekonomi termasuk kategori "Sangat Kuat" karena berada pada selang 0,80 1,000 .

\section{SIMPULAN}

Berdasarkan analisis data dan pembahasan sebagaimana diuraikan pada bab sebelumnya maka dapat diambil beberapa kesimpulan, yakni sebagai berikut :

1. Fundamental ekonomi daerah yang terdiri dari pertumbuhan ekonomi, pendapatan perkapita serta IPM memiliki pengaruh yang signifikan terhadap pembangunan ekonomi baik secara simultan maupun secara parsial.

2. Besarnya pengaruh fundamental ekonomi daerah terhadap pembangunan ekonomi adalah sebagai berikut:

a. Secara Simultan

Nilai F hitung sebesar 529,104 sedangkan $\mathrm{F}$ tabel $(\alpha=0.05$; $\mathrm{db}$ regresi $=4: \mathrm{db}$ residual $=2$ ) adalah sebesar 19,25. Karena F hitung > F tabel yaitu 529,104 > 19,25 maka analisis regresi adalah signifikan. Hal ini berarti H0 ditolak dan H1 diterima sehingga dapat disimpulkan bahwa pembangunan ekonomi di Kota Sungai Penuh tahun 2010-2015 dapat dipengaruhi secara signifikan oleh variabel bebas fundamental ekonomi daerah yaitu variabel pertumbuhan ekonomi, pendapatan perkapita dan IPM.

b. Secara Parsial

1) t hitung $X 1$ (pertumbuhan ekonomi) $=4,836$ dan $\mathrm{t}$ tabel sebesar 2,920. Karena $t$ hitung > t tabel yaitu 4,836 $>2,920$ serta dari tabel diperoleh nilai signifikansi 0,008, maka pengaruh X1 (pertumbuhan ekonomi) adalah signifikan. Hal ini berarti $\mathrm{H} 0$ ditolak dan $\mathrm{H} 1$ diterima, sehingga dapat disimpulkan bahwa pembangunan ekonomi di Kota Sungai Penuh dapat dipengaruhi secara signifikan oleh variabel pertumbuhan ekonomi secara nyata. Dari nilai koefisien diketahui bahwa pertumbuhan ekonomi memiliki pengaruh sebesar $0,139 \%$ terhadap pembangunan ekonomi.

2) $t$ hitung $X 2$ (pendapatan perkapita) $=6,813$ dan $\mathrm{t}$ tabel adalah sebesar 2,920. Karena $\mathrm{t}$ hitung $>\mathrm{t}$ tabel yaitu $6,813>2,920$ serta dari tabel diperoleh nilai signifikansi 0,019 , maka pengaruh X2 (pendapatan perkapita) adalah signifikan. 
Hal ini berarti H0 ditolak dan $\mathrm{H} 1$ diterima, sehingga dapat disimpulkan bahwa pembangunan ekonomi di Kota Sungai Penuh dapat dipengaruhi secara signifikan oleh variabel pendapatan perkapita secara nyata. Dari nilai koefisien diketahui bahwa pendapatan perkapita memiliki pengaruh sebesar $0,886 \%$ terhadap pembangunan ekonomi.

3) t hitung $X 3$ (IPM) $=6,602$ dan $\mathrm{t}$ tabel sebesar 2,920. Karena $\mathrm{t}$ hitung $>\mathrm{t}$ tabel yaitu $6,602>2,920$ serta dari tabel diperoleh nilai signifikansi 0,027, maka pengaruh X3 (IPM) adalah signifikan. Hal ini berarti HO ditolak dan H1 diterima, sehingga dapat disimpulkan bahwa pembangunan ekonomi di Kota Sungai Penuh dapat dipengaruhi secara signifikan oleh variabel IPM secara nyata. Dari nilai koefisien diketahui bahwa IPM memiliki pengaruh sebesar 2,366\% terhadap pembangunan ekonomi.

\section{DAFTAR PUSTAKA}

Arsyad, Lincolin (2002). Pengantar

Perencanaan

dan

Pembangunan Ekonomi

Daerah, Yokyakarta : Fakultas Ekonomi Universitas Gadjah Mada.

Badan Pusat Statistik. (2008). Statistik Sosial dan Kependudukan Hasil Susenas Tahun 20012007. Jakarta : BPS.

Badan Pusat Statistik. (BPS) Kota Sungai Penuh (2016). Produk Domestik Regional Bruto Kota Sungai Penuh Menurut Lapangan Usaha 2011-2015.

Badan Pusat Statistik. (BPS) Kota Sungai Penuh (2015). Sungai Penuh Dalam Angka 2014.

Badan Pusat Statistik. (BPS) Kota Sungai Penuh (2016). Sungai Penuh Dalam Angka 2015.
Bank Dunia. (2008). Mengoptimalkan Kontribusi Desentralisasi Bagi Pembangunan : Metodologi Kerangka Kerja Pengukuran Kinerja Pemerintah Daerah (LGPM). Decentralization Support Facility (DSF), www.dsfindonesia.org.

Bank Pembangunan Asia. (2007). Kebijakan ADB Mengenai Gender dan Pembangunan. (online).

translation/indonesian/kebijaka n_gender_id.pdf.

Boediono (2004). Teori Pertumbuhan Ekonomi. BPFE : Yogyakarta.

Cebula, R.D. dan Toma Garvi, M.G. (2008). Gender Inequality and Economic Growth in Spain : An Exploratory Analysis. The Review of Regional Studies Vol. 39 No. 1 pp. 23 - 48.

$\begin{array}{cr}\text { Jhingan } \quad \text { (2000), } & \text { Ekonomi } \\ \text { Pembangunan } & \text { dan } \\ \text { Perencanaan. } & \text { Penerjemah } \\ \text { Guritno. } & \text { Penerbit PT } \\ \text { RajaGrafindo Persada : Jakarta. }\end{array}$

Kuncoro, Mudrajad (2004). Otonomi dan Pembangunan Daerah : Reformasi, Perencanaan, Strategi, dan Peluang, Jakarta : Erlangga.

kebijakan (2010). Masalah,
Ekonomika Pembangunan.
Jakarta : Erlangga.
Mangun, P. Eko (2007). "Kinerja
Pembangunan Ekonomi
Daerah Kabupaten Semarang",
Jurnal Asset, STIE Widya
Manggala Semarang.

Rahardja, O.B. dan Manurung, R. (2008). Hubungan Kesetaraan Gender, Kemiskinan dan Pertumbuhan Ekonomi: Analisis Data Susenas 2000. Warta Demografi Tahun 34, No. 4, 2004, hal. 6-21.

Riduwan. (2008). Dasar-Dasar Statistika. Bandung : Alfabeta.

Rudatin, Gunawan (2003). "Membangun Perekonomian Rakyat". Pustaka Pelajar

dan Institut Development Economic Analysis, Yogyakarta. 
Sadono Sukirno (2004). Pengantar Teori Mikro Ekonomi. Raja Grafindo Persada, Jakarta.

Sjafrizal (2014). Perencanaan Pembangunan Daerah Dalam Era Otonomi, Jakarta: PT. Raja Grafindo Persada.

Soepranto (2002). Metode Penelitian Suatu Pendekatan Proposal. Jakarta : Bumi Aksara.

Suryana (2002). Ekonomi Pembangunan. Salemba Empat, Bandung.

Sumodiningrat. (2007). Metode Penelitian Administrasi. Alfabeta, Bandung.

Suwandono, Sudrajat. (2007).

"Struktur Fundamental dan Kinerja Perekonomian : Pendekatan analisis InputOutput dan SNSE". Laporan Penelitian.

Tarigan, Robinson. (2005). Perencanaan Pembangunan Wilayah.Jakarta : Bumi Aksara.

Todaro, M.P (2006). Pembangunan Ekonomi (edisi kesembilan). Jakarta : Erlangga.

United Nation Development Programme (1995). Human Development Report : Gender and Human Development. New York, USA : UNDP.

UNSFIRS. (2000). "ORANI-G: A General Equilibrium Model of The Australian

Economiy". Central of Policy Studies and Impact Project Preliminary Working paper No. OP-93, Monash University, October, Downloadable From: http://www.monash edu.au/policy/op-93.htm

Vantina, dkk. (2008). Keadilan Gender dalam Pengambilan Kebijakan : Antara Harapan dan Kenyataan (Studi Kasus Pada Sekretariat Daerah Kota Samarinda Tahun 2008). Jurnal Sosial-Politika, Vol.15, No.1.

Zen, Roumasset (2002). Teori Mikroekonomi. Terjemahan. Jakarta : Binarupa Aksara 